\title{
Analisis Peran Pemerintah Dan Masyarakat Dalam Sektor Ekonomi Melalui Finalisasi Kebijakan
}

\begin{tabular}{|c|c|}
\hline \multicolumn{2}{|c|}{ 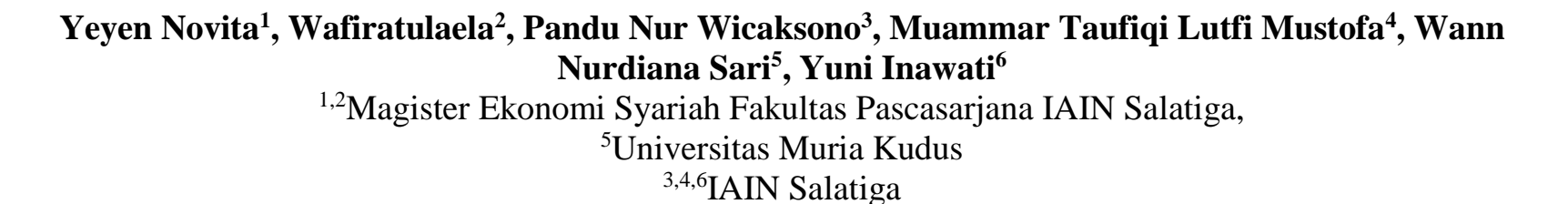 } \\
\hline Article Info & Abstract \\
\hline $\begin{array}{l}\text { Article history: } \\
\text { Accepted: 10 Januari } 2022 \\
\text { Publish: } 11 \text { Januari } 2022\end{array}$ & $\begin{array}{l}\text { One of the processes carried out by the government and the community to manage } \\
\text { existing resources through collaboration between the government and the private } \\
\text { sector is one of the meanings of economic development. This is done in the context of } \\
\text { creating job opportunities as well as efforts to encourage economic growth in a } \\
\text { region. Thus, it is important for the government and the community to play a role in }\end{array}$ \\
\hline $\begin{array}{l}\text { Keywords: } \\
\text { The role of society } \\
\text { Government } \\
\text { economic policy }\end{array}$ & $\begin{array}{l}\text { solving macroeconomic problems. The final objective of this research is to analyze } \\
\text { in depth the concept of the three-sector economy, the rationality of the role of } \\
\text { government and society, the scope of the government's role, government policy } \\
\text { instruments and an overview of al-hisbah. This study uses a literature study where } \\
\text { information is obtained through a collection of books, a collection of scientific works, } \\
\text { several theses, encyclopedias, a little information from the internet and even other } \\
\text { sources. Research shows that in the economy three sectors are played by } 3 \text { roles } \\
\text { including households, companies and the government. The rationality of the } \\
\text { government's role is based on the consequences of collective obligations, and the } \\
\text { failure of the market to realize falah. The analysis of the government's role includes: } \\
\text { the role of allocation, distribution, stabilization, the role of the state in overcoming } \\
\text { externalities and the role of the state related to the implementation of Islamic } \\
\text { morality. There are also three policies that cover, among others: fiscal policy, } \\
\text { monetary policy, and supply-side policy. Some basic thinking about the role of society } \\
\text { consists of the consequences of fardhu kifayah, the existence of public property rights } \\
\text { and the failure of the market and government. While hisbah is an institution } \\
\text { controlled by the government through individual efforts specifically assigned to solve } \\
\text { problems related to the moral, religious and economic fields. }\end{array}$ \\
\hline Info Ar & ABSTRACT \\
\hline $\begin{array}{l}\text { Article history: } \\
\text { Diterima: } 10 \text { Januari } 2022 \\
\text { Terbit: } 11 \text { Januari } 2022\end{array}$ & $\begin{array}{l}\text { Salah satu proses yang dilakukan pemerintah dan masyarakat guna mengelola sumber } \\
\text { daya yang ada melalui kerjasama antara pemerintah dan swasta merupakan salahsatu } \\
\text { makna pembangunan ekonomi. Hal ini dilakukan dalam rangka penciptaan lapangan } \\
\text { kerja beserta upaya mendorong pertumbuhan ekonomi suatu wilayah. Dengan begitu } \\
\text { menjadilah penting adanya peran pemerintah dan juga masyarakat dalam } \\
\text { menyelesaikan masalah perekonomian makro. Tujuan akhir dari penelitian ini guna } \\
\text { menganalisis secara mendalam tentang konsep perekonomian tiga sektor, rasionalitas } \\
\text { peran pemerintah dan masyarakat, ruang lingkup peran pemerintah, instrumen } \\
\text { kebijakan pemerintah dan sekilas tentang al-hisbah. Penelitian ini menggunakan studi } \\
\text { kepustakaan dimana informasi didapat melalui sekumpulan buku, kumpulan karya } \\
\text { ilmiah, beberapa tesis, ensiklopedia, sedikit informasi dari internet dan bahkan } \\
\text { sumber-sumber lain. Penelitian menunjukan hasil bahwa di dalam perekonomian tiga } \\
\text { sektor dimainkan oleh } 3 \text { peran meliputi rumah tangga, perusahaan dan pemerintah. } \\
\text { Rasionalitas peran pemerintah didasari atas adanya konsekuensi kewajiban kolektif, } \\
\text { dan kegagalan pada pasar dalam upaya realisasi falah. Analisis peran pemerintah } \\
\text { diantaranya: peran alokasi, distribusi, stabilisasi, peran negara dalam mengatasi } \\
\text { eksternalitas dan peran negara berkaitan dengan implementasi moralitas islam. } \\
\text { Terdapat pula tiga kebijakan yang mencangkup antara lain: kebijakan fiskal, } \\
\text { kebijakan moneter, dan kebijakan segi penawaran. Beberapa dasar pemikirian peran } \\
\text { masyarakat terdiri aras konsekuensi fardhu kifayah, adanya hak milik publik dan }\end{array}$ \\
\hline
\end{tabular}




\begin{tabular}{|l|c|}
\hline & $\begin{array}{l}\text { adanya kegagalan pada pasar dan pemerintah. Sedangkan hisbah merupakan lembaga } \\
\text { yang dikontrol oleh pemerintah melalui usaha perorangan yang ditugaskan secara } \\
\text { khusus guna menyelesaikan permasalahan yang berkaitan dengan bidang moral, } \\
\text { bidang agama dan juga bidang ekonomi. }\end{array}$ \\
\hline & This is an open access article under the Lisensi Creative Commons Atribusi- \\
\hline $\begin{array}{l}\text { Corresponding Author: } \\
\text { Yeyen Novita, } \\
\text { Magister Ekonomi Syariah Fakultas Pascasarjana IAIN Salatiga } \\
\text { Email: yeyen4210@gmail.com }\end{array}$
\end{tabular}

\section{PENDAhuluan}

Salah satu proses pemerintah dan masyarakat sebagai upaya pengelolaan sumber daya yang ada melalui kerjasama antara pemerintah dan swasta merupakan salahsatu makna pembangunan ekonomi. Hal ini bertujuan dalam rangka penciptaan lapangan kerja dan pendorong pertumbuhan ekonomi pada suatu wilayah. Hal ini menjadikan pemerintah dan masyarakat berperan penting dalam menyelesaikan masalah perekonomian makro. Peran pemerintah bertujuan untuk meningkatkan kesejahteraan, membangun ekonomi daerah dengan membentuk pola kerjasama diantara pemerintah dan sektor swasta guna pembentukan lapangan pekerjaan baru serta dapat memicu perkembangan sektor ekonomi dalam lingkup wilayah. Untuk itu, pihak pemerintah daerah dengan didukung oleh partisipasi masyarakat diprediksi mampu manaksir potensi dari sumber daya yang dirasa perlu guna membangun ekonomi daerah. Dalam hal ini yang diperlukan yakni tempat transaksi sebagai tempat terjadinya transaksi ekonomi yang disebut pasar.

Sistem perekonomian menjadi sangat beraneka ragam, yang kemudian membuat sistem ekonomi dimaknai sebagai suatu organisasi ekonomi yang baik dan teratur. Maka dari itu, pemerintah memiliiki peran yang penting dalam kestabilan perekonomian suatu Negara seperti halnya proses pengaturan jumlah penerimaan negara, kemudian kebijakan dalam upaya pengatasan eksternalitas negatif dan beberapa hal lainnya. Pada dasarnya pemerintah berpengaruh pada perekonomian di tingkat yang berbeda. Terdapat pemerintah yang dalam pengaturan perekonomiannya dilakukan dengan cara yang ketat dan intensif. Terdapat pula pembatasan bahwasanya hal ini dianggap sebagai pendukung perekonomian saja. Peran pemerintah dalam bidang ekonomi yaitu secara umum berfungsi untuk membantu pengembangan bisnis, sebagai pendorong persaingan usaha yang sehat dan membantu kelompok ekonomi lemah dan yang terakhir berfungsi sebagai stabilizer.Untuk mengetahui secara mendalam maka perlu untuk dibahas mengenai analisis peran pemerintah dengan beberapa sub bahasan meliputi: konsep perekonomian tiga sektor, rasionalitas peran pemerintah dan masyarakat, ruang lingkup peran pemerintah, instrumen kebijakan pemerintah dan sekilas tentang al hisbah.

\section{METODE PENELITIAN}

Metode penelitian bermakna sebagai metode ilmiah guna mendapatkan dengan memiliki tujuan yang khusus. Metode ini juga dimaknai sebagai cara untuk mengumpulkan data untuk kemudian juga menganalisis data yang didapat. Data yang diperoleh selanjutnya dikembangkan guna memperoleh wawasan baru melalui aturan yang reliabel dan terpercaya. Penelitian ini mempergunakan studi kepustakaan, dimana bermakna suatu kegiatan guna menyerap berbagai infromasi yang benar dan sejalan dengan topik yang sedang diangkat sebagai obyek dari penelitian. Informasi yang dimaksud didapat dari berbagai sumber kepustakaan meliputi sekumpulan buku, kumpulan karya ilmiah, beberapa tesis, ensiklopedia, sebagian kecil dari internet dan bermacam sumber lainnya (Milya Sari, 
2020). Diharapkan dengan adanya penelitian ini, peneliti mampu menggunakan manfaat dari informasi dan pemikiran yang benar dan cocok dengan penelitiannya di masa mendatang.

\section{HASIL TEMUAN DAN PEMBAHASAN}

\section{a. Perekonomian Tiga Sektor}

Perekonomian tiga sektor diartikan sebagai sistem ekonomi yang terdiri atas pihak perusahaan, pemerintah dan pihak rumah tangga. Analisis pada perekonomian tiga sektor, maka hakikatnya memperhatikan pengarh dan juga peran pemerintah didalam sektor ekonomi (Darwin, 2020). Menurut teorinya, terdapat dua perubahan penting yang terlaksana pada penentuan keseimbangan pendapatan nasional yang dipengaruhi oleh campur tangan pemerintah. Perubahan tersebut diantaranya tentang adanya pungutan pajak yang direalisasikan oleh pemerintah diproyeksikan mampu mengurangi jumlah belanja nasional dengan pengurangan atas belanja rumah tangga dan pajak yang memungkinkan pemerintah untuk melaksanakan pengeluaran. Dengan hal ini akan menjadikan perbelanjaan agregat menjadi meningkat. Perubahan ini membawa pengaruh utama pada keseimbangan pendapatan nasional. Di dalam pelaksanaannya, perekonomian tiga sektor meniadakan kegiatan ekspor impor maka secara umum dikenal dengan perekonomian tertutup.

Analisa keseimbangan pada pendapatan nasional dalam perekonomian tiga sektor memiliki tujuan untuk menentukan pendapatan nasional kaitannya dengan peran pemerintah. Campur tangan pemerintah memancing munculnya 3 aliran dalam sirkulasi aliran pendapatan, diantaranya:

a. Pembayaran atas pajak oleh perusahaan dan rumah tangga kepada pihak pemerintah. Pembayaran pajak menjadikan pendapatan kepada pihak pemerintah. Hal ini digunakan sebagai sumber dari pendapatan pemerintah yang penting/utama.

b. Pengeluaran dari pihak pemerintah kepada pihak perusahaan. sistem ini menjelaskan besar pembelanjaan pemerintah atas pembelian produk yang diproduksi perusahaan.

c. Pendapatan dari pihak pemerintah kepada pihak rumah tangga. Aliran ini tercipta sebab adanya pembayaran konsumsi atas determinan produksi yang telah dimiliki pihak rumah tangga oleh pihak pemerintah.

Berikut ini adalah gambaran ketiga aliran dalam perekonomian tiga sektor:

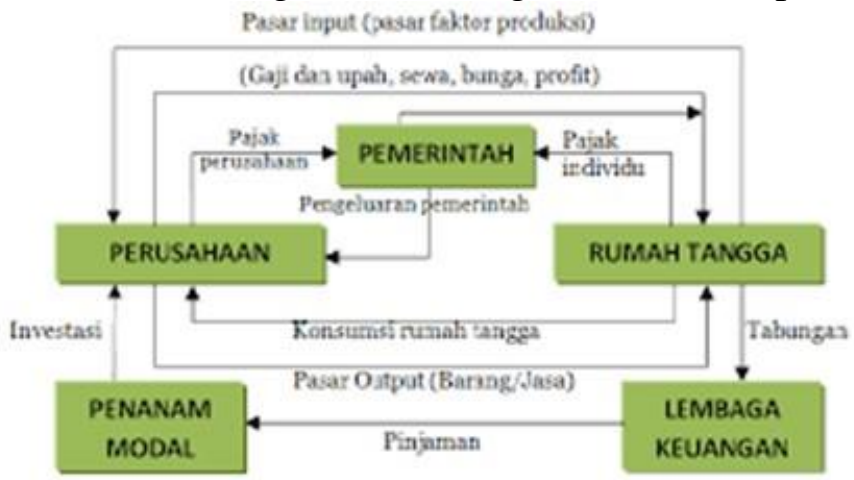

Gambar 1. Sirkulasi Aliran Pendapatan Perekonomian 3 Sektor

Pada gambar 1 tersebut kita dapat melihat bahwasanya perekonomian tertutup dapat dijalankan sesuai dengan alur berikut ini:

a Transaksi pembayaran yang dilakukan oleh pihak perusahaan saat ini dapat digolongkan atas 2 macam meliputi transaksi pembayaran pihak rumah tangga yang selanjutnya dianggap pendapatan atas penjualan faktor produksi dan transaksi pembayaran atas pajak pendapatan perusahaan serta pemerintah. 
b Sektor rumah tangga memperoleh pendapatan dari 2 sumber yaitu pembayaran atas gaji dan upah, pembayaran sewa, pembayaran bunga dan keuntungan perusahaan serta didapat dari pembayaran atas gaji dan upah yang dilakukan pemerintah

c Sumber pendapatan pemerintah berasal dari pihak perusahaan dan pihak rumah tangga atas pembayaran pajaknya. Pendapatan tersebut selanjutnya digunakan untuk membayar gaji dan upah pegawai serta pembelian barang dan jasa oleh pemerintah

d Pendapatan yang didapatkan oleh rumah tangga (Y) diproyeksikan untuk pemenuhan 3 kebutuhan yaitu pembayaran dan pembiayaan konsumsi (C), tabungan (S), dan pajak (T) yang selanjutnya ditulis sebagai rumus $\mathrm{Y}=\mathrm{C}+\mathrm{S}+\mathrm{T}$.

e Pelaksanaan alur perekonomian tiga sektor, tabungan yang bersasal dari rumah tangga selanjutnya dipinjamkan oleh lembaga keuangan kepada mereka (pengusaha) yang menanam modal untuk dikelola lebih lanjut.

f Dalam pelaksanaan pengeluaran agregat (AE) perekonomian tiga sektor, jenisnya semakin bertambah menjadi diantaranya consumption xxpenditure $(\mathrm{C})$ dan invesment $(\mathrm{I})$, dan juga government spending $(\mathrm{G})$. Selanjutnya diperoleh persamaan: $\mathrm{AE}=\mathrm{C}+\mathrm{I}+\mathrm{G}$.

Dalam suatu perekonomian, Jika penawaran agregat bernilai sama dengan pengeluaran agregat maka tercapailah keseimbangan pendapatan nasional. Seperti halnya dalam perekonomian tiga sektor yang tidak melibatkan perdagangan luar negeri, maka penawaran agregat disama artikan dengan pendapatan nasional (Y). Sehingga dengan hal tersebut terciptalah rumus $\mathrm{Y}=\mathrm{C}+\mathrm{I}+\mathrm{G}$. Hal yang sama dengan pendapat nasional adalah aliran pendapatan dimana merupakan kegiatan sektor perusahaan untuk memproduksi barang dan jasa. Pendapatan rumah tangga selanjutnya akan digunakan untuk 3 komponen meliputi (T) Pajak, (S) Tabungan dan (C) konsumsi sehingga berlaku persamaan $\mathrm{Y}=\mathrm{T}+\mathrm{S}+\mathrm{C}$

Berdasar pada uraian di atas, telah ditunjuk hasil bahawasanya di dalam keseimbangan telah dirumuskan $\mathrm{Y}=\mathrm{C}+\mathrm{I}+\mathrm{G}$ dimana setiap nominal pendapatan nasional masuk dalam persamaan $\mathrm{Y}=\mathrm{C}+\mathrm{S}+\mathrm{T}$ dengan demikian selanjutnya berlaku rumus $\mathrm{C}+\mathrm{I}+\mathrm{G}=\mathrm{C}+\mathrm{S}+\mathrm{T}$ yang apabila diformulasikan maka akan menjadi $\mathrm{I}+\mathrm{G}=\mathrm{S}+\mathrm{T}$. Dengan begitu, keseimbangan ekonomi tiga sektor dapat berlaku kesimbangan yang dapat dijelaskan pada rumus:

$$
\mathrm{Y}=\mathrm{C}+\mathrm{I}+\mathrm{G} \text { dan } \mathrm{I}+\mathrm{G}=\mathrm{S}+\mathrm{T}
$$

\section{b. Rasionalitas Peran Pemerintah dalam perekonomian}

Tanggungjawab yang dilakukan pemerintah bukan hanya sebatas atas keamanan maupun sistem dari keamanan yang memiliki power antisipatif serangan dari luar, tetapi pertanggungjawaban yang dilakukan pemerintah harus menjadi bagian dari program pencapaian oleh masyarakat, menjadi makmur dan bersifat adil. Tanpa keterlibatan pemerintah, menjadi hal mustahil keasalian bisa tercapai. Pemerintah dinilai mampu memberikan jaminan sosial termasuk kasus permasalahan ekonomi. Peranan pemerintah dalam ekonomi islam memiliki dasar yang amat kokoh, pandangan islam memaknai hal tersebut atas argumentasi berikut:

1) Konsekuensi adanya kewajiban kolektif (fardh-kifayah)

Pemerintah ialah pemegang amanah yang diberikan Allah guna melakukan tugas secara bersama-sama yang bertujuan untuk menciptakan kemaslahatan umat manusia. Dengan begitu, secara otomatis pemerintah juga menjadi pemegang amanah masyarakat. Konsep fardh kifayah merujuk pada segala kepentingan masyarakat yang apabila dilakukan oleh satu orang maka menjadi gugur kewajiban orang lain untuk mengerjakannya. Dalam hal ini yang dimaksud adalah terkait pemenuhan kebutuhan akan jenis transportasi, tingkat pendidikan, kualitas pelayanan medis dan lainnya. Pemerintah memiliki peran penting dalam mengimplementasikan tugasnya disebabkan oleh gagalnya masyarakat untuk menjalankan tugas. Kemungkinan kegagalan masyarakat disebabkan oleh beberapa hal diantaranya: kekurangan informasi, pelanggaran terhadap moral, kekurangan sumber data manusia. 
Dengan dasar tersebut, maka menjadi penting kiranya untuk pemerintah mengambil alih tugas tersebut demi kesejahteraan dan keadilan bersama.

2) Kegagalan pasar dalam mencapai falah

Dalam hal ini pemerintah dimaknai sebagai agen dari Tuhan atau yangs ering kita dengar dengan istilah khalifatullah guna mewujudkan falah. Dengan fungsinya sebagai pemegang amanah dari Tuhan, maka menjadikan peran dari pemerintah tetap eksis menjadi landasan tetap dalam firman Allah SWT dan Hadist yang tertuang dengan implisit ataupun eksplisit. Nabi Muhammad SAW sebagai suri tauladan telah mencontohkan dalam kehidupannya untuk kemudian dicontoh oleh pemerintah. Musyawarah merupakan pengambilan keputusan terbaik sepanjang sejarah untuk menjunjung tinggi prinsip keadilan.

\section{c. Ruang lingkup peran pemerintah}

Dalam upaya mewujudkan keinginan masyarakat, negara memiliki peran penting yaitu meningkatkan standar dan kualitas atas hidup. Dalam hal ini, negara perlu memberikan jaminan dan kepastian bahwasanya seluruh masyarakat mempunyai peluang dalam penggunaan sumber daya ekonomi. Hal tersebut menjadikan negara harus mengatur dan mendistribusikan pengaruh terhadap penggunaan sumberdaya ekonomi dengan cara adil dan merata. Teori ekonomi islam menunjukkan bahwa negara akhirnya mempunyai kontribusi penting dalam sektor ekonomi. Ulama mendukung hal tersebut dengan menambahkan bahwasanya negara dalam pelaksanaan tugasnya harus dilakukan secara adil dan dekokratis. Maksudnya adalah segala keputusan yang diambil dilaksanakan dengan cara musyawarah dengan melibatkan wakil dari rakyat. Meski agama islam memberi peran kepada negara dengan lingkup yang luas, namun hal ini tidak memberi makna bahwa konsep islam mengesampingkan kemerdekaan seorang individu.

Terdapatnya kegagalan pasar menjadikan bukti bahwa pemerintah harus melakukan campur tangan dalam ekonomi secara optimal. Tujuan campur tangan pemerintah meliputi beberapa hal yaitu menjamin persamaan akan hak setiap individu dan penghapusan penindasan, menjamin sektor ekomomi supaya tumbuh dan dapat berkembang, melakukan pengawasan terhadap perusahaan monopoli yang dianggap mendominasi pasar agar tidak melakukan kegiatan yang merugikan, menjadi penyedia barang-barang yang digunakan publik meliputi pembangunan jalan raya, pendirian sekolah dan penguatan keamanan dalam rangka peningkatan kesejahteraan untuk masyarakat, serta pengurangan eksternalitas atas aktivitas perekonomian yang diprediksi tidak akan memberikan keuntungan.. alam sector ekonmi peran pemerintah diidentifikasikan seperti berikut ini:

1) Peranan Alokasi

Dalam hal ini pemerintah memiliki peran sebagai penyedia alat-alat ekonomi yang secara fungsional berguna untuk masyarakat dan dalam pengadaannya tidak dapat dihasilkan dari pihak swasta. Hal ini yang dimaksud adalah kebutuhan publik seperti pembangunan jalan, pendirian rumah sakit, sekolah dan penguatan keamanan. Pada dasarnya, sumber daya milik negara memiliki jumlah yang terbatas, sehingga pemerintah dengan sumber dayanya diharuskan mengutamakan keperluan barang publik dan sebagiannya digunakan untuk penyediaan barang individu.

2) Peranan Distribusi

Dalam hal ini pemerintah memiliki peran untuk dapat mendistribusikan kekayaan dan juga pendapatan negara yang diperuntukkan demi kesejahteraan masyarakat. Dengan begitu, pemerintah dengan sigap membuat kebijakan dengan upaya alokasi sumber daya agar dapat disalurkan dengan merata melalui pembayaran perpajakan, pemberian subsidi, upaya pemberatasan kemiskinan, pemberian santunan pendidikan, penjamaminan bantuan kesehatan dan implementasi batuan perbaikan daerah. Dengan dibuatnya kebijakan itu maka pemerintah digadang dapat melengkapi fungsinya dalam pendistribusian pendapatan dan kekayaan untuk kesentosaan bagi masyarakat. Sama halnya subsidi bagi penduduk kurang 
mampu yang dananya bersumber dari dana penarikan pajak dan dana pemerataan pembangunan infrastruktur yang dapat menjangkai wilayah pelosok dan jauh atau seperti dalam pembangunan proyek jalan di wilayah terluar Indonesia.

3) Peranan Keseimbangan

Seperti kita tahu bersama bahwasanya perekonomian yang rentan terhadap guncangan keadaan yang menjadi sebab terciptanya pengangguran dan inflasi adalah perekonomian yang sepenuhnya dipercayakan pada sektor privat. Maka itu, pemerintah mempunyai peran yang sangat penting sebagai alat stabilisasi ekonomi. Peranan pemerintah yang dimaksud dilakukan dengan berbagai cara yang tujuannya adalah permasalahan ekonomi tidak menjalar kepada sektor lain. Selain itu juga bertujuan untuk mengendalikan inflasi dengan menggunakan kebijakan yang telah dibuat. Sebagai contoh dalam upaya penanganan monopoli pasar, pemerintah memiliki peran utama dalam pengendaliannya dengan melakukan pengendalian harga dan pengenaan pajak.

4) Peran Negara dalam Mengatasi Eksternalitas

Eksternalitas ekonomi atau yang bisa disebut dengan disekonomi dimaknai sebagai peristiwa yang dapat memberikan keuntungan yang cukup besar atau bahkan kerugian yang cukup besar pula pada beberapa pihak yang tidak ikut serta penuh dalam proses pengambilan keputusan. Seorang tokoh peneliti bernama Corner dan Sandler memaknai eksternalitas sebagai sebuah kerangka institusi yang lebih khusus yaitu pasar kompetitif. Dalam pengertian lain, eksternalitas bermakna imbas yang nantinya ditanggung oleh pelaku ekonomi atas dasar aktivitasnya. Dalam pelaksanaanya, sangatlah berpengaruh efisiensi alokasi sumber daya dan distribusi perekonomian.

5) Peran Negara dalam Mengimplementasikan Moralitas Islam

Politik ekonomi islam menyatakan bahawasanya negara memiliki tugas dalam hal bertanggungjawab atas kegiatan ekonomi dengan tujuan menegakkan keadilan dan mencegah terjadinya kedzaliman. Usaha ini dapat dilakukan dengan menggunakan kekuatan pemerintah. Seperti halnya dalam surat Al-Hadid ayat 25 yang memaknai bahwasanya fungsi negara adalah sebagai penegak keadilan ekonomi, pasar dan menjamin pemenuhan kebutuhan dengan cara pengaturan infrastruktur disertai sistem penjaminan sosial.

\section{d. Instrumen kebijakan pemerintah}

Ilmu tentang ekonomi makro mempelajari perihal kasus dan permasalahan yang berkenaan dengan masalah pengangguran, lapangan pekerjaan, inflasi, deflasi, angka pengangguran dan jumlah lowongan pekerjaan yang tersedia. Di Dalam lingkup ekonomi yang luas kaitannya dengan pemerintah memiliki beragam jenis kebijakan yang dibuat. Kebijakan tersebut berfungsi sebagai cara untuk mengatasi permasalahan ekonomi makro. Terdapat 3 kebijakan yakni Kebijakan segi penawaran, kebijakan moneter, dan kebijakan fiskal (Naf'an, 2013).

\section{1) Kebijakan Fiskal}

Salah satu bentuk peran pemerintah yang sangat uatama dalam sistem ekonomi islam adalah kebijakan fiskal jika dibandingkan kebijakan moneter. Implikasi dari pelarangan riba dan pelarangan kewajiban membayar zakat menunjukkan betapa perlunya keberadaan kebijakan fiskal dibanding dengan keberadaan moneter (Syaakir Soryan, 2016). Kebijakan fiskal ialah kebijakan yang diberlakukan pemerintah guna mengendalikan pertumbihan sektor ekonomi dengan melalui pengeluaran dan pemasukan sektor pemerintah (Minarni, 2014). Kebijakan fiskal sangatlah penting untuk menyelesaikan masalah yang berkenaan dengan pengangguran. Dengan adanya kebijakan fiskal, angka pengeluaran agregat dapat ditingkatkan dan cara ini tentunya akan meningkatkan jumlah pendapatan agregat serta meningkatkan angka penyerapan tenaga kerja. Kebijakan fiskal ini juga digunakan sebagai cara pemerintah untuk membuat perubahan dalam bidang perpajakan dan belanja pemerintah dengan maksud memberikan pengaruh pada pengeluaran nasional di sistem perekonomian. Maksud tersebut khusus dari kebijakan fiskal, meliputi: retirbusi pendapatan, stimulasi pertumbuhan ekonomi dan koreksi atas ketidakseimbangan sementara. 
M Umer Chapra menulis kebijakan fiskal telah menjadi alat utama negara makmur yang meliputi penggunakan pengeluaran publik, perpajakan progresif dan pinjaman utang untuk merealisasikan tujuan yang diinginkan. pendapatan dan belanja nasional adalah hal yang diatur dalam kebijakan fiskal. pendapatan negara bisa didapatkan dari pajak masyarakat. Selain itu, pemasukan negara lainnya adalah dari lelang, denda, hibah, dan pendapatan non pajak lainya.

Kebijakan pmerintah fiskal dibedakan 2 macam kebijakan yaitu ekspansif dan kontraktif, pengertian keduanya bisa dibedakan seperti berikut ini:

1. Kebijakan fiskal ekspansif merupakan kebijakan ekonomi dengan cara menurunkan pendapatan negara seperti pajak dan meningkatkan belanja pemerintah sehingga output akan meningkat.

2. Kebijakan fiskal kontraktif merupakan bentuk kebijakan pemerintah guna mempengaruhi pendapatan agar lebih besar daripada pengeluarannya. Tujuan utamanya adalah menurunkan tingkat daya beli masyarakat dan mengatasi inflasi.

\section{2) Kebijakan Moneter}

Kebijakan moneter merupakan langkah Bank Indonesia guna mengendalikan uang yang beredar seperti menaikan atau menurunkan tingkat suku bunga dengan tujuan untuk memberikan pengaruh terhadap belanja nasional. Kebijakan moneter dibagi menjadi 2 yakni kebijakan ekspansi dan kebijakan kontraktif. Penjelasan untuk kebijakan ekspansi dimaknai sebagai kebijakan yang pelaksanannya diisiasi dalam upaya menambah jumlah uang yang sedang beredar. Berbeda halnya dengan jenis kebijakan kontraktif yang dimaknai sebagai kebijakan untuk menurunkan jumlah uang yang sedang beredar. Setidaknya terdapat tiga jenis instrumen yang ditujukan untuk keperluan pengaturan jumlah uang yang sedang beredar meliputi: operasi pasar terbuka, kebijakan diskonto, dan rasio cadangan wajib. Terdapat pula kebijakan lain selain ketiga kebijakan tersebut yang berbentuk himbauan moral

\section{1) Kebijakan operasi pasar terbuka}

Kebijakan operasi pasar terbuka merupakan kebijakan yang bertujuan untuk pengendalian uang beredar dengan melakukan jual beli sukuk atau surat berharga pemerintah. Kegiatan ini dilakukan dalam rangka implementasi kebijakan operasi pasar terbuka dapat dilakukan di pasar primer dan sekunder. Kegiatan berupa jual beli surat berharga, kemampuan liquid bank akan berkurang sehingga pemberian kredit juga akan berkurang disebabkan oleh keinginan bank sentral untuk menaikan atau menurunkan jumlah uang yang beredar (Safuridar, 2018).

\section{2) Kebijakan Diskonto}

Kebijakan ini laksanakan dengan menaikan tingkat suku bunga dari Bank Sentral pada bank umum sebagai pengendalian jumlah uang. Fasilitas kredit yang diberikan kepada beberapa bank dengan jaminan surat berharga serta tingkat diskonto yang ditetapkan oleh Bank Indonesia dan sesuai dengan kebijakan moneter.

\section{3) Rasio Cadangan Wajib}

Kebijakan ini bermakna bahwasanya peran pemerintah yaitu dalam rangka mangatur dan menentukan dana cadangan, dimana dana tersebut telah disimpan kepada penerintah dan telah dipenuhi oleh bank umum dalam memberikan kredit terhadap masyarakat. Dalam kebijakan ini terdapat istilah cadangan wajib minimum yang bermakna jumlah alat likuid dengan batas minimum yang wajib diperlihara oleh bank. Cadangan yang dimaksud telah diklasifikasikan menjadi 2 meliputi cadangan primer dan cadangan sekunder. 


\section{4) Kebijakan Kredit Selektif}

Kebijakan ini dilaksanakan guna meminimalisir jumlah uang yang sedang beredar. Peranan pemerintah dalam hal ini adalah sebagai penentu sebab diberikannya kredit yang diajukan oleh masyarakat yang bersangkutan

\section{5) Kebijakan Himbauan Moral}

Kebijakan ini dilakukan dengan menghimbau masyarakat dalam perihal pembayaran kredit dan juga transaksi menabung dan pembiayaan atau apapun yang berkenaan dengan transaksi bank. Kebijakan ini juga mengarahkan bank umum sebagai upaya meminjam uang dalam jumlah lebih kepada bank sentral sebagai upaya memperbanyak jumlah uang beredar di perekonomian indonesia. Himbauan ini bersifat tidak mengikat dan tidak berakibat hukum.

6) Politik Sanering

Politik sanering merupakan tindakan pemerintah dalam rangka pemotongan daya beli masyarakat dengan cara mengurangi nilai uang tetapi harga barang tidak berubah sehingga akibatnya yakni pada menurunnya daya beli masyarakat (Joseph J.A. Turambi a, 2015).

\section{7) Devaluasi}

Kebijakan ini dilaksanakan oleh bank sentral dalam rangka penurunan nilai mata uang rupiah terhadap jumlah mata uang asing yang sedang mengalami peningkatan.

\section{3) Kebijakan Dari Segi Penawaran}

Kebijakan dari segi penawaran ditujukan supaya dapat menambah efisien suatu kegiatan yang dilaksanakan oleh perusahaan sehingga diharapkan dapat menawarkan produk dengan memperoleh harga murah didukung dengan kualitas yang jauh lebih bagus. Satu diantara contoh kebijakan segi penawaran ialah kebijakan pendapatan atau yang sering dikenal dengan incomes policy. Hal tersebut yang dimaksud adalah langkah pemerintah dengan tujuan pengendalian tuntutan atas kenaikan upah buruh. Hal ini bertujuan untuk mencegah adanya peningkatan pendapatan yang melebihi batas. Pihak pemerintah akan kemudian melarang tuntutan yang dilontarkan atas upah yang dianggap melebihi peningkatan produktivitas pekerja. Kebijakan yang ada akan menghindarkan peningkatan biaya produksi yang berlebihan. Kebijakan segi penawaran yang lainnya ditekankan pada peningkatan semangat pekerja dalam rangka untuk bekerja serta peningkatan kegiatan para pengusaha dalam rangka peningkatan efisiensi usaha produksi.

Implementasi kebijakan segi penawaran selain dengan pengadaan peningkatan semangat bekerja dan pemberian intensif kepada perusahaan dapat pula dilaksanakan dengan pengembangan infrastruktur dan juga peningkatan kualitas layanan pemerintah dalam rangka pengembangan kegiatan industry swasta. Insfrastruktur yang dinilai lebih bagus kualitasnya dan memiliki regulasi yang bersifat kondusif memiliki peran utama dan penting dalam pengembangan kegiatan industri swasta dan menaikan efisiensi kegiatanya (Veritia, 2019).

\section{e. Rasionalitas peran masyarakat}

Keberadaan masyarakat dalam sistem perekonomian memiliki kedudukan yang sama dengan pasar dan pemerintah. Beberapa dasar rasionalitas peran masayarakat adalah sebagai berikut:

1) Konsekuensi Fardhu Kifayah

Hukum Fardhu kifayah adalah keharusan yang ditujukan kepada sekelompok masyarakat secara bersama-sama. jika kewajiban ini tinggalkan, maka seluruh masyarakat akan mendapatkan dosa, sedangkan jika salah satu dari masyarkat telah melaksanakan maka kewajiban masyarakat telah gugur. Walaupun pemerintah lebih mampu bertindak efektif karena pengetahuan yang lebih luas daripada masyarakat, namun masyarakat memiliki kewajiban turut serta dalam penjaga kesembangan perekonomian.

2) Adanya Hak Milik Masyarakat 
Rasionaitas peran masyarakat dikarenakan adanya hak milik masyarakat yaitu waqaf. Harta wakaf sepenuhnya milik publik yang tidak ada capur tangan pemetintah sehingga pengelolaan dipegang oleh masyarakat.

3) Kegagalan Pasar dan kegagalan pemerintah

Ketiga pada dan pmerintah tidak berhasil memberitan tatanan mekanisme pasar yang stabil maka sudah saatnya asayarakat turut serta seperti penemtuan harga komoditas tertentu. Kebijakan pemerintah yang sering bersebrangan dengan kepentiangan masayarakat juga menjadi alasan rasionalitan peran masyarakat. Maka kedudukan masayarakat diantara pasar dan pemerintah adalah penting.

\section{4) Sekilas Al -Hisbah}

\section{1) Definisi Al-Hisbah}

Menurut bahasanya al-hisbah merupaka masdar dari fi'il (حسبة) berasal dari kata berbahasa Arab yang berarti menimbang atau menghitung. Ibnu Taimiyah mengartikan secara istilah sebagai badan atau lembaga untuk menegakan kebenaran dan menyerukan untuk meninggalkan keburukan. Al-Hisbah merupakan lembaga seperti pengaman dalam kegiatan perekonomian (M. Arif Hakim, 2015). Lembaga ini merupakan suatu badan atau rganisasi bebas yang terlepas dari kepentingan suatu organisasi tertentu atau pemerintah.

Hisbah adalah suatu badan organisasi yang diberikan tugas oleh pemerintah baik secara individu maupun kelompok untuk menangani berbagai bidang khususnya bidang ekonomi (Mujahidin, 2012). Fungsi lembaga ini secara umum berkenaan atas kegiatan kolektif atau publik dalam rangka mencapai keadilan dan mencari kebenaran menurut sudut pandang Islam. Seperti yang disebutkan oleh Muhammad Muslehuddin memberikan penjelasan bahwasanya lembaga al-hisbah adalah institusi yang berciri islam dimana muhtasib mempunyai tugas mengawasi kegiatan di pasar agar tertib. Muhammad al-Mubârak juga menyatakan bahwasanya hisbah ialah lembaga atau organisasi yang sengaja didirikan sejak peradapan Islam dengan tujuan memberi pengawasan pada aktifitas perdagangan bersih dari praktik ekonomi yang pelaksanaanya ditentang oleh agama islam.

Begitu juga dengan pernyataan peneliti bahwasanya sejarah Al-Hisbah dalam Islam dimulai langsung oleh Nabi Muhammad SAW beliau adalah Muhtasib atau pelaksana alhisbah (Rakhmawati, 2016). Pada praktiknya, beliau mengawasi secara langsung aktivitas pasar dengan terjun secara langsung di pasar Madinah. Hingga suatu ketika beliau bertemu dengan penjual yang menimbun gandum. Beliau langsung memberikan plajaran saat ini juga kepada penjual yang tidak berbuat jujur. Setiap pelanggaran yang beliau temukan akan mendapat teguran disertai nasihat untuk memperbaikinya. Di sinilah inti dari tugas alhisbah.

\section{2) Tugas dan Wewenang Al-Hisbah}

Berdasarkan kesepakatan sebagian besar ulama fiqih, wewenang al-hisbah meliputi seluruh kegiatan yang tidak sesua dengan prinsip amar ma'ruf dan nahi munkar, tidak termasuk wewenang lembaga keadilan baik yang berhubungan dengan kegiatan ibadah taupun aqidah (Rozalinda, 2014). Kegiatan muamalah seperti hokum jual beli jug menjadi wewenang ahisbah sehingga tercipta kegiatan ekonomi yang tertib sesuai dengan ajaran islam.

Menurut A.A Islahi fungsi al-hisbah secara umum adalah sebagai pelaksana kebaikan yang berkaitan dengan moral dan melakukan pengawasan secara langsung terhadap pasar. Bebeapa tigas utama lembaga alhisbah adalah sebagai berikut:

1. Melakukan pengawasan terhadap ketersediaan komoditas barang dan jasa di pasar memastikan tidak terjadi kelangkaan pada komoditas tertentu. 
2. Pengawasan terhadap standar produk dan menjatuhkan sanksi kepada produsen yang merugikan masyarakat. muhtasib juga dapat mengeluarkan peraturan dalam kegiatan industry seperti hak pekerja dalam mengambil cuti, waktu kerja upah dan lain sebagainya yang menyangkut kesejahteraan pekerja.

3. Muhtasib harus memelihara pasar secara umum dan berbagai praktik jual beli seperti timbangan dan ukuran. Muhtasib harus menjamin para pelaku dagang melakukan kegiatan jual beli sesuai syariat islam, misalnya tidak ada praktik riba dan menjual barang halal.

4. Al-hisbah memiliki peran dalan penataan tata ruang kota dan pasar sesuai ketentuan hokum memberikan jaminan rasa aman dan nyaman bagi seluruh masyarakat.

5. Muhtasib harus menjaga kamanan pasar agar persaiangan dagang dapat berjalan secara harmonis dan islami serta tidak ada pihak yang dirugikan. Seperti memusnahkan praktik penimbunan riba dan penghapusan syarat untuk keluar dan masuk pasar.

\section{KESIMPULAN DAN SARAN}

Perekonomian tiga sektor bermakna sebuah sistem ekonomi yang melibatkan peran rumah tangga, pihak perusahaan serta pihak pemerintah. Dalam hal ini terdapat campur tangan pemerintah yang nantinya menumbuhkan sebanyak 3 aliran yang meliputi pembayaran pajak dari pihak rumah tangga dan pihak perusahaan kepada pemerintah, pengeluaran dari pemerintah kepada pihak perusahaan, dan pendapatan yang diperoleh dari sektor pemerintah kepada sektor rumah tangga. Keseimbangan dicapai saat berlaku rumus $\mathrm{Y}=\mathrm{C}+\mathrm{I}+\mathrm{G}$ dan $\mathrm{I}+\mathrm{G}=\mathrm{S}+\mathrm{T}$.

Dasar rasionalitas dalam ekonomi islam atas peranan pemerintah mencangkup beberapa argumentasi meliputi: konsekuensi terkait adanya kewajiban yang kolektif (fardh kifayah) dan kegagalan pada pasar dalam merealisasikan falah. Pernanan pemerintah dalam sektor ekonomi dapat diklasifikasikan dalam beberapa kelimpok, antara lain: peranan alokasi, distribusi, stabilisasi, peran negara dalam mengatasi eksternalitas dan peran negara berkaitan dengan implementasi moralitas Islam.

Terdapat tiga jenis kebijakan meliputi kebijakan fiskal, kebijakan moneter, dan kebijakan segi penawaran. Pemikiran yang mendasari peranan masyarakat meliputi konsekuensi fardhu kifayah, adanya hak milik publik dan kegagalan pasar dan pemerintah. Sedangkan untuk al hisbah, dimaknai sebagai lembaga yang dalam pelaksanaannya dikontrol oleh pemerintah dengan melalui usaha yang diselenggarakan oleh perorangan. Tugas dari lembaga ini adalah menyelesaikan permasalahan agama, bidang ekonomi maupun moral secara khusus.

\section{DAFTAR PUSTAKA}

Darwin, R. (2020). Determinan Pertumbuhan Ekonomi Dalam Model Perekonomian Tiga Sektor. Jurnal Akuntansi Dan Ekonomika, 10(1), 31-40. https://doi.org/10.37859/jae.v10i1.1921

Joseph J.A. Turambi a. (2015). Redenominasi dan Sanering Mata Uang Rupiah (IDR): Analisis Komparasi. Jurnal EBBANK, 06(1), 91-99.

M. Arif Hakim. (2015). PERAN PEMERINTAH DALAM MENGAWASI MEKANISME PASAR DALAM PERSPEKTIF ISLAM. Iqtishadia, 8(1).

Milya Sari. (2020). Penelitian Kepustakaan (Library Research) dalam Penelitian Pendidikan IPA. NATURAL SCIENCE: Jurnal Penelitian Bidang IPA Dan Pendidikan IPA, 6(1), 41-53.

Minarni. (2014). Falsifikasi Kebijakan Fiskal di Indonesia Perspektif Islam. Graha Ilmu.

Mujahidin, A. (2012). Peran Negara dalam Hisbah. Al-Iqtishad, 4(1).

Naf'an. (2013). Ekonomi Makro: (Tinjauan Ekonomi Syariah). Graha Ilmu.

Rakhmawati, A. (2016). Implementasi lembaga hisbah dalam meningkatkan bisnis Islam. Jurnal Malia, Universitas Brawijaya Malang, 7(2). 
Jurnal Ilmu Sosial dan Pendidikan (JISIP) ～e-ISSN : 2656-6753, p-ISSN: 2598-9944

Rozalinda. (2014). Ekonomi Islam: Teori dan Aplikasinya Pada Aktivitas Ekonomi. PT RajaGrafindo persada.

Safuridar. (2018). Peranan Instrumen Kebijakan Moneter Terhadap Pertumbuhan Ekonomi di Aceh. Jurnal Samudra Ekonomika, 2(1), 38-52.

Syaakir Soryan. (2016). PERAN NEGARA DALAM PEREKONOMIAN (Tinjauan Teoritis Kebijakan Fiskal dalam Ekonomi Islam). Hunafa: Jurnal Studia Islamika.

Veritia, D. (2019). Teori Ekonomi Makro. Unpam Press. 